\title{
Summary of: \\ Morale of vocational dental practitioners in the United Kingdom
}

\section{FULL PAPER DETAILS}

${ }^{1}$ General Dental Practitioner, 27 High Street Chasetown, Burntwood, Staffs, WS7 3XE; ${ }^{2 *}$ Lecturer in Conservative Dentistry, University of Birmingham, School of Dentistry, St Chad's Queensway, Birmingham B4 6NN

${ }^{*}$ Correspondence to: Mr Dominic A. Stewardson Email:d.a.stewardson@bham.ac.uk

Online article number E18

Refereed Paper - accepted 28 January 2008

DOI: $10.1038 /$ sj.bdj.2008.401

${ }^{\circ}$ British Dental Journal 2008; 204: E18

\author{
J. Gilmour ${ }^{1}$ and D. A. Stewardson ${ }^{2}$
}

(B)

\begin{abstract}
Objective This study was undertaken to devise a suitable survey instrument to measure morale, and to undertake an assessment of morale amongst vocational dental practitioners (VDPs) in the UK. Design Postal questionnaire survey. Setting Dental vocational training schemes in the UK. Subjects Vocational dental practitioners. Method A confidential postal questionnaire was used to measure levels of morale among all VDPs in the UK in 2007. Results A response rate of 76.7\% was achieved. The mean morale score for Scottish VDPs was significantly higher than that of the Northern Irish VDPs, which in turn was significantly higher than those of the VDPs in England or Wales. In England and Wales females recorded higher morale scores than males. Lowest morale scores were associated with statements referring to concerns about future changes to NHS dentistry, and the limits on treatment within the NHS system. The highest scores were associated with good working relationships. Conclusion The use of an appropriately tested questionnaire has provided a convenient objective measure of morale. The morale of VDPs in the United Kingdom was lower than expected. Scottish VDPs recorded higher morale scores than other VDPs and responded more positively in the survey instrument. The most negative responses from all VDPs were regarding the effect of the NHS system on treatment and concerns about future changes to the NHS.
\end{abstract}

\section{EDITOR'S SUMMARY}

It is not entirely surprising that the morale of VDPs in England and Wales is significantly lower than that of their peers in Northern Ireland and, in turn, in Scotland. The past two or so years since the introduction of the new NHS contract in England and Wales have done little to raise the morale of dentists of all ages and at all stages of their careers, not just those venturing out at the beginning.

What is sad is not only that a need for such a study has arisen but also that this survey confirms the sorry state of affairs. One might expect that there is an element of low morale based on a perception about the future conjured from a lack of experience. But even taking this as a minor explanation, what a sorry picture it paints of the view of young people embarking on a career in dentistry. A career for which they have studied for five years as undergraduates and which, presumably, when they were 13 or 14-years-old appealed to them as a worthwhile profession and a livelihood to which to aspire.

Other recent research on the satisfaction of dentists showed that being in control of their own working conditions and decision making rated very highly. Higher in fact than financial gain. To some extent it is possible to divine a similar pattern here, the essential difference being that older practitioners have the experience and wherewithal to be in greater charge of their own destiny than a VDP. It is possible for an optimist to speculate that things will improve and that the VDPs who took part in this survey will have a brighter future than they themselves currently perceive. In the interim it is a very unfortunate reflection on our profession that so many of our young colleagues are starting their professional journey on such a depressingly low note.

The full paper can be accessed from the $B D J$ website (www.bdj.co.uk), under 'Research' in the table of contents for Volume 204 issue 11.

Stephen Hancocks, Editor-in-Chief

DOI: 10.1038/sj.bdj.2008.507 


\section{TO ACCESS THE BDJ WEBSITE TO READ THE FULL PAPER:}

- BDA members should go to www.bda.org

- Do not login on the BDA home page, if you are already logged in, please log out.

- Then, in www.bda.org click on the link to the BDJ in the top left of the screen. A new window will open. If a new window fails to open please check the settings of any pop up blocker software that you have installed on your computer.

- You will now be asked to login with your BDA website login details which are on your BDA membership card.

- Once your details have been entered you will be transferred to the BDJ website. If your login does not work please contact the BDA Membership Department on 02075634550.

- If you are not able to access the article on the BDJ website there may be an issue with your system's firewall. If so, return to the BDA homepage and click on the link 'BDJ access problems' and follow the step by step guide.

\section{COMMENT}

This interesting piece of work was aimed specifically at a large group of new graduates undertaking vocational training in various centres throughout the UK. The study was to measure morale among vocational dental practitioners across England, Wales, Scotland and Northern Ireland.

Many other studies have looked at morale among general dental practitioners and also general medical practitioners in relation to changes in contractual arrangements within the NHS. The value of this survey is that it looked specifically at VDPs and compared morale scores between Scotland, Northern Ireland, England and Wales. Not surprisingly, as the authors highlight, the changes in England and Wales in April 2006 for the re-organisation of General Dental Services were probably the most fundamental since the inception of the National Health Service. Scotland and Northern Ireland did not go through this reorganisation. The questionnaire by the authors did highlight some of the negativity that exists around the new contract in England and Wales as perceived by vocational dental practitioners. The overall low levels of morale reported are very worrying; England and Wales having a greater proportion of morale scores below 50\%.

The higher levels of morale in Scotland were linked to more positive feelings regarding their value as NHS dentists and further training opportunities within the NHS.

Many of the English and Welsh VDPs according to this work felt negatively about working within the current NHS and felt their limitations of treatments for their patients and possible employment in the future were of concern.

Throughout the study, the validity of the data collected would seem to be high and the higher response rate of $76.7 \%$ is to be commended and supports the strength of the data collected. As this study was carried out shortly after the introduction of the contract in England and Wales; it may be useful, as the authors suggest, to repeat the study so the effect of the changes of the new contract arrangements may well have taken time to settle down.

This research paper, although giving an impression of low morale among vocational dental practitioners, would be worth repeating on a regular basis as the low levels of morale among young dentists cannot be acceptable when judged against the quality standards of professionals working within the NHS.

\section{B. Grieveson, Postgraduate Dental Dean - Mersey Deanery}

IN BRIEF

- Provides a measure of morale among VDPs throughout the UK.

- Universal concern was evident regarding future changes in the NHS, the limits on treatment within the current NHS system and earning enough.

- English and Welsh VDPs were worried about being able to work in the locality and a practice that they liked.

- Continued monitoring of changes in morale is possible using this survey instrument.

\section{AUTHOR QUESTIONS AND ANSWERS}

1. Why did you undertake this research? It would be expected that the introduction of new working conditions would raise anxieties amongst those involved. The latest changes to the general dental services contract are huge and arguably may have the most serious implications for those completing vocational training. The availability of practice positions and location is likely to be restricted and there will be difficulties securing employment. However, would VDPs be aware of the problems with which they would soon have to cope, and as a result were they as optimistic about their career as one would hope they would be? We were therefore interested in devising a means of gauging the morale of VDPs.

2. What would you like to do next in this area to follow on from this work?

Having created a measure for morale, we intend to repeat this survey with successive cohorts of VDPs to monitor if morale remains low. In particular, what effects on morale will follow any changes to the NHS contract which are introduced when the current arrangements are reviewed in 2009? It would also be of interest to monitor the morale of each cohort at different time periods after they have completed their VDP year and begin independent practice and to compare the morale of British dentists on graduation with that of dentists in other countries. 